\title{
UNIVERSAL HEALTH COVERAGE MANAGEMENT BASED ON TRI HITA KARANA IN THE REGENCY OF KLUNGKUNG, BALI
}

\author{
Suciari Luh Sri*, Gorda A.A.N. Eddy Supriyadinatha \\ Undiknas Graduate School, Universitas Pendidikan Nasional, Bali, Indonesia \\ *E-mail: uciksetiawan@yahoo.com
}

\begin{abstract}
Klungkung Regency with the third lowest PAD (regional GDP) succeeded in declaring Universal Health Coverage (UHC) after Badung Regency. The study aims to determine the Universal Health Coverage (UHC) Management Based on Tri Hita Karana in Klungkung Regency, Province of Bali. The research design used was qualitative research with in-depth interview methods. The things that underlie the success of UHC in Klungkung Regency are the high commitment of the highest policy makers in Klungkung Regency, namely the Regent of Klungkung by not setting aside all other stakeholders such as the Klungkung Regional Secretary, the head of the Health office, the head of the social service office, and the BPJS (Social Security Administrator for Health) itself and other regional organisation who helped this success. Another basis is good management that has been applied in accordance with management principles. As well as community awareness itself which considers that health is a very important thing. The principle of justice, a relationship that must be balanced and harmonious is the most fundamental basis for this success. Tri Hita Karana - which is a philosophy - plays a very strong role in the success of government. Turns out that Tri Hita Karana has been applied in UHC Management in Klungkung Regency, both when examined from the theory of behavior, the theory of the principle of justice and management theory. Suggestions in this research is on the concept of pawongan, it is expected that the organizers and implementers will ensure that information about JKN (National Healthcare), type, membership, flow etc. can be socialized more frequently and more targeted to all communities.
\end{abstract}

\section{KEY WORDS}

Management, universal health coverage, Tri Hita Karana, human resources.

Health is a development goal and basic capital in a country's development (Dianaputra \& Aswitari, 2015). Basic Health Research Data (Riskesdas) in 2018 with 300,000 household samples (1.2 million people) illustrates an increase in the prevalence of Non-Communicable Diseases (PTM) when compared with Riskesdas 2013. These diseases include cancer, stroke, chronic kidney disease, diabetes mellitus, and hypertension. Cancer prevalence rose $0.4 \%$ from $1.4 \%$ (Riskesdas 2013 ) to $1.8 \%$; stroke prevalence increased by $3.9 \%$ from $7 \%$ to $10.9 \%$; and chronic kidney disease rose by $1.8 \%$ from $2 \%$ to $3.8 \%$. Based on blood sugar tests, diabetes mellitus rose by $1.7 \%$ from $6.9 \%$ to $8.5 \%$; and blood pressure measurement results, hypertension rose by $8.3 \%$ from $25.8 \%$ to $34.1 \%$. Likewise with mental illnesses increased by $5.3 \%$ from $1.7 \%$ to $7 \%$ (Ministry of Health of Republic of Indonesia, 2018). The health care system that has been established in Indonesia is known as the National Health Insurance (JKN). This guarantee is managed by a body formed by the government, namely the Health Social Security Administration Agency (BPJS Kesehatan). BPJS Health is a StateOwned Enterprise (BUMN) whose duty is to provide health care guarantees for all Indonesian people who are assigned specifically by the Government of the Republic of Indonesia (Suryani \& Suharyanto, 2016). The BPJS of health was ratified on January 1, 2014, so that from that date the general public is expected to register for JKN membership. As for the poor, BPJS contributions are borne by the government through the Contribution Assistance Recipient (PBI) program. In addition, people who work as State Civil Apparatus (ASN) have directly become members of JKN membership (Hardy \& Yudha, 2018).Pemerintah menargetkan Indonesia akan mencapai Universal Health Coverage (UHC) 
atau cakupan kesehatan menyeluruh bagi seluruh penduduk Indonesia pada tanggal 1 Januari 2019. Setiap tahun BPJS Kesehatan menargetkan jumlah penduduk yang menjadi peserta terus bertambah dari 156,7 juta jiwa (2015) dan seluruh penduduk pada 2019. Dari Website BPJS Kesehatan diketahui bahwa sampai bulan Juni tahun 2019 rencana tersebut belum bisa terlaksana sepenuhnya.

According to data from the Health BPJS in 2018, in Indonesia there have been as many as four provinces, 28 cities and 92 districts successfully achieving universal health coverage or Universal Health Coverage (UHC). The provinces of Aceh, Jakarta, Gorontalo and West Papua are the four provinces that have reached UHC. Although the province of Bali is not included in the four provinces referred to, but there are several districts in Bali that have reached UHC, namely Badung and Klungkung districts. The two districts that are the pioneers of UHC in the province of Bali. When viewed from BPS data for 2017, both districts have inversely proportional Local Revenue (PAD). Badung Regency has an area of 418.62 $\mathrm{km}^{2}$ with various tourism sectors and other sectors that can be used as sources of PAD ranked number one in the data while Klungkung District with an area of $315 \mathrm{~km}^{2}$ which is classified as small districts has PAD number seven in Bali province. According to BPS data for 2017, the Klungkung regency has a PAD of 153 million while Badung has a PAD of four billion.

Klungkung regency's PAD compared to 9 regencies is still classified as a regency that has a small income. However, from the Klungkung District Health Profile data for 2018, the Klungkung Regency Government has budgeted the Klungkung public health funding in full, so that it becomes a pioneer District that can meet UHC in Bali Province with low PAD. The successful achievement of UHC is certainly supported by good management but it does not cover the possibility that there are other foundations that are local geniuses which instead become the basis of the success of UHC in Klungkung Regency. One of these Local Geniuses is Tri Hita Karana. Tri Hita Karana illustrates the concept of a balanced relationship between humans and God, humans and other humans, and humans and the environment. In a study conducted by Mulyawan, Wirama, and Badera in 2017 stated that the Tri Hita Karana Culture is a moderating variable that can strengthen Good Corporate Governance (GCG). This illustrates that the implementation of this concept can improve the results of government performance. For this reason, researchers want to study Universal Health Coverage Management (UHC) in Klungkung Regency to harmonize with the concept of Tri Hita Karana as a basis.

\section{METHODS OF RESEARCH}

This study uses a qualitative research design with in-depth interview methods. This research was conducted in Klungkung Regency. There are 2 data collection in this research, namely document study and direct interview. The selection of informants is based on their position, knowledge and data obtained from sources by describing phenomena related to the topic. The technique used is purposive sampling (sampling data sources with certain considerations). The selected resource persons for this study are: Klungkung Regent, Klungkung Regency Regional Secretary, Head of Participation in the Klungkung Regency BPJS, Klungkung District Health Office Head, Klungkung Regency Social Service Head, Community Participants of JKN Mandiri who chose the First Health Facility in the UPTD. Klungkung I health center and at UPTD Dawan II Health Center. The validity of the data in this study, carried out through the stage of checking the credibility of the data by means of triangulation. The collected data is then processed using qualitative descriptive techniques.

\section{DISCUSSION OF RESULTS}

Klungkung Regency is one of the regencies in the Province of Bali. It has an area of $315 \mathrm{~km}^{2}$, with 59 village with a population of 178,300 people consisting of 88,200 men and 90,100 women (Klungkung District Health Office, 2018). Klungkung District Health Profile states the results of coverage of Health Insurance membership in Klungkung Regency in 
2018 have reached $128.5 \%$, with the percentage of the number of PBI APBN and PBI APBD higher than the percentage of Non PBI participants (Klungkung District Health Office, 2018). For the latest data obtained, based on the Minutes of Reconciliation of the number of JKN contributions and contributions between BPJS Klungkung Health Branch and the Social Service for Women Empowerment and Child Protection, Klungkung Regency dated November 4, 2019 membership data was $102.666 \%$. These shows a decrease in the form of the success of monitoring and evaluation as well as the cooperation of relevant parties in validating the data so that there are found problems such as dual membership due to the problematic NIK (national personal identification number).

Self-participation can actually reduce the burden on district governments in financing $\mathrm{JKN}$. Behavior of independent participation in JKN is influenced by several things, namely: knowledge, beliefs, basic needs, a sense of humanity and perceived benefits. As the results of research conducted by Rohmawati, 2018 in her study entitled Relationship of Family Knowledge about BPJS (Social Security Organizing Agency) With Family Behavior in Participating in the BPJS Program, states that:

«There is a relationship between respondents' knowledge about BPJS and the behavior of respondents in joining the BPJS program in RT 001 RW 001 Tenggarejo village, Tanggunggunung District, Tulungagung Regency».

Besides basic needs in this case the need for health, comfort when sick, trust, love are factors that influence one's behavior as expressed by Abrham Maslow. The existence of benefits or something that is obtained is also the basis of one's behavior. In his research Irwan (2017) states that one that causes behavior is something that is obtained. So that if things that can encourage community behavior to become independent participants while still paying attention to the family's financial capacity can be improved either through increased knowledge and understanding of BPJS including its benefits, superior principles, and other motivations can be considered, improved it is possible to increase the number of independent participants so that district funding is lighter. Even though Klungkung Regency has a high commitment related to the universal guarantee that must be owned by the people. The principle of justice is not only explained by stakeholders who reveal that actually health and health services must be obtained by everyone, but the community is aware that its ability to pay premiums independently can make people less able to get justice because they can help and do not take rights from disadvantaged people.

Another influence on culture in Bali, especially in Klungkung Regency, one of which is Tri Hita Karana. Tri Hita Karana is a local culture that comes from local wisdom, so it can be said as a national culture, where factors such as ethnicity, economy, politics, religion, or language contribute to the formation of national culture. This culture that has grown and developed in Balinese society has been used as a philosophy of social life and the foundation of business philosophy towards balance and harmonization can be said to be a national culture (Suardhika \& Budiasih, 2017). The balance between these three relationships, both human relations with God, humans with humans and humans with the environment will bring health, well-being and peace to their lives. In this case the concept of Tri Hita Karana has been revealed to be the basis in the development of both village developments, governance including UHC in Klungkung Regency. Because it cannot be denied that all actions taken are based on human nature for the welfare of society which is nothing but one of the relationships that illustrates the relationship between humans and humans, besides belief in God is believed to be able to bring intellectual property that can make humans more critical, more aware of common interests and be more creative in acting. While the relationship with the environment is not only described in the environment that looks social environment, physical good is a safe situation, a clean environment is also the basis of it.

Parhyangan is a concept from Tri Hita Karana who wants harmony between humans and God Almighty (Suardhika \& Budiasih, 2017). When viewed from this dimension, the success of UHC in Klungkung Regency cannot be separated from human relations with God. Parhyangan studies based on the theory used are as follows. 
Human behavior is based on belief in God. All speakers believe that by believing in God, praying, praying to Him they believe they believe will be given smoothness, health, and happiness. As stated by Wiwik's mother who is Muslim stated that:

"Ngih all religions are the same, in my opinion God is where we are, right, you know you can't say yes, every breath must remember God, everything we do is because of God, we work because of God, the same good neighbors also because of God".

The mother of one child also has a belief that everything is done according to God's will. Human behavior can be avoided in relation to God. All religions teach the good of every behavior based on good relations with God the Creator is most likely not to deviate from the teaching of goodness. Indonesia especially in Bali and Klungkung itself deeply recognizes and values diversity including religious diversity. As revealed by Dewantara (2015) which states that:

«The Indonesian people recognize the existence of religions, and there should be mutual respect between them, because thus the Indonesian nation can be called a civilized nation»

«Parhyangan» which is a local wealth of Hindu genius but has a Universal nature. In this case the recognition of the behavior carried out will again be accountable to God. Saputra (2018) states that:

«THK's teaching concept, Prahyangan, teaches a harmonious relationship between humans and God. This teaching automatically instructs that all actions taken by the Sudaji Village Apparatus in the framework of managing village funds that are very vulnerable to fraud must be accountable to God. Of course all the actions of the village apparatus are accountable to the Creator in the form of praying before and after carrying out the village development program plan as a form of moral responsibility and a form of gratitude to the Creator «

In this study all the speakers have a good relationship with God can be seen from direct observations that have been made where all the sample houses of the Hindu religion when visited must have a canang / banten, the office is always plangkiran, apart from the results of direct interviews stating that all believers will God. The policy maker in this case is the Regent of Klungkung I Nyoman Suwirta himself believes in God as much as he has come to the Nyinep Ceremony at Kahyangan Temple Jagad Dasar Bhuana Gelgel

So it can be concluded that the parhyangan dimension based on behavior theory both by policy makers, implementers and JKN users has become the basis directly or indirectly in UHC management in Klungkung Regency.

In the Law of the Republic of Indonesia Number 36 of 2009 concerning health stated:

"That health is a human right and one of the elements of well-being that must be realized in accordance with the ideals of the Indonesian people as referred to in the Pancasila and the 1945 Constitution of the Republic of Indonesia» (MOH RI, 2009). The principle of justice referred to comes from Pancasila and the 1945 Constitution both of which uphold the values of the Almighty God. God teaches people to be fair, give rights that should be accepted, not take the rights of others. This has been applied in UHC in Klungkung Regency.

The Parhyangan concept when associated with management theory is a basis for making decisions. Because everything that is taken from the planning, implementation of activities and so on always comes from the human's own belief in what is the goal of the organization in this case achieving universal security in terms of health in Klungkung Regency. The goal is none other than belief in something good and beneficial for many people. This belief is the basis in efforts to improve the welfare of society by leaders, organizers and users, namely the community itself. One of the most obvious things is seen during monitoring and evaluation meetings where joint prayer is always done before the activity starts. In making a decision, both written and unwritten, it is always based on the Godhead. So from the 4 management functions, planning is the function that best describes the relationship with God, ideas and intellectual property sourced from God can be a planning capital and this is seen in the initial planning of UHC in Klungkung Regency. However other functions that can work well are also influenced by the balance of this 
relationship. So the concept of parhyangan in management theory is the basis for UHC management in Klungkung Regency.

Pawongan / human which is one of the concepts of Tri Hita Karana is a subject as well as an object, in the sense that humans in their lives determine and are determined by themselves, if the concept is applied ideally, harmony will be achieved and vice versa if humans do not apply the concept, they do not will find harmony in his life (Suardhika \& Budiasih, 2017). Relationships between people with one another, describe the limitations of humans themselves as imperfect creatures. Based on this, humans cannot live alone, humans have limitations that can be complemented by other humans. The study of this pawongan dimension when related to the theory of UHC management in Klungkung Regency is as follows:

Behavior on this dimension is most clearly seen because the things revealed in the interview are explicitly revealed that encourage community behavior are basic human needs such as: feelings of compassion among others, both the family itself, and with the community, especially the poor. Besides being a basic need for motivation which is one of the drivers of one's behavior is clearly visible. As explained by Prastiwi, Ningsih and Suardika (2019) stated that:

«Human behavior is the result of all kinds of human experience and interaction with the environment which is manifested in the form of knowledge, attitudes and actions. In other words, behavior is the response / reaction of an individual to stimuli that come from outside or from within. This response can be passive (without action: think, think, act) or be active (take action). In accordance with this limitation, health behavior can be formulated as a form of experience and interaction of individuals with their environment, especially those concerning knowledge and attitudes about health. Active behavior can be seen, while passive behavior does not appear, such as knowledge, perception, or motivation».

Motivations obtained in this study such as:

1) From JKN participants independently: the desire to help others, ease the burden on others, make others comfortable, do not want to burden loved ones when they are sick and get better health services for families.

2) From the Klungkung regency government: want to improve the degree of public health by ensuring that all people in Klungkung with a residence in Klungkung Regency receive health insurance.

Another behavior theory, namely The Health Belief model theory on the perceived benefits component was also found in this study. The user community has benefited from its participation as an independent JKN participant so that although it is recorded to get free funding they refuse because they feel the benefits and benefits more than the use of membership as an independent JKN participant. These things are a picture of the harmonious relationship between humans and humans. The concept of pawongan describes social interaction, where social interaction can occur if between two individuals or groups there is social contact and communication (Ayuni, Gorda \& Budiasni, 2019). In addition to the foregoing behavioral relationship that can be seen which is also one of the social interactions is the relationship between the leader and its members. In this case the leadership carried out by the Regent Suwirta to move the entire DPOs and related staff involved and do things that were previously doubtful successes into something that has been implemented as a commitment of the District is a success in an effort to convince, influence and invite for the goals certain that is none other than UHC Klungkung Regency. Pinatih and Gorda (2017) state that:

"Leadership is the art of influencing others in an organization that is led, with a common goal without coercion to be able to realize what is the vision and mission of the organization».

So it can be seen that the management of UHC in Klungkung Regency from the aspect of pawongan in Tri Hita Karana has indeed been carried out and is in accordance with existing behavior theories.

When viewed from the principle of justice in the pawongan dimension, it is clearly seen that the government implements justice based on the fifth principle, namely social justice for 
all Indonesian people. This is in accordance with research conducted by Yandrizal, Rifa'il and Utami (2015) who concluded that the majority of people who have not become JKN participants are because they are unable. To provide justice, the Klungkung regency government pays premium contributions to the community in terms of Contribution Aid Recipients (PBI) originating from the APBD.

When viewed from this pawongan dimension, the relationship between people in UHC management in Klungkung Regency is very clear where the Team Decree was made in its implementation. From the initial planning, organizing, implementation to monitoring and evaluation, it is clearly illustrated that there is a harmonious relationship between fellow human beings both in terms of the organizers, implementers and users themselves. Can be explained here when planning the calculation of needs, costs and so forth have seen a harmonious relationship between the leader and the Regional Organization (OPD) related. Good coordination from the Regent, Regional Secretary, and the team both the Health Office, Social Service, Dukcapil, BPJS, Village / Kelurahan and the community itself is one of the most important supports. In addition, monitoring and evaluation have been carried out routinely and gradually. Supports from the collaboration and harmony that provide sweet fruit in the form of UHC Commitment in Klungkung Regency Management is not just talking about managers or leaders, but all those involved in it for that in terms of management, it is clear that good human relations produce good results.

This is consistent with research conducted by Saputra, Anggiriawan and Sutapa (2018) which states that:

«Hindu people view harmonious collaboration with fellow human beings as one of the principles of the success of a person or organization in achieving their stated goals».

So it can be concluded that the concept of pawongan based on management theory on UHC management in Klungkung Regency has indeed been implemented.

Palemahan is a concept related to the harmonious relationship between humans and the surrounding natural environment. THK dimension of the weakening field is related to the physical aspects of the environment around us. This dimension is associated with management activities that should pay attention to the natural environment and the external environment (Suardhika \& Budiasih, 2017).

When examined from the theory of behavior, based on direct observations / observations that have been made the behavior of keeping the environment clean, the trash that are in the yard of the house and office, the neat arrangement of the room illustrates the harmony between humans and their environment. This is indirectly related to UHC management where health can be obtained from protecting the environment itself. In addition, the changing times that occur are at this time which is an industrial revolution 4.0, making humans in this case both the government, organizers, executors and JKN users must follow the era. Where in its implementation will always be associated with science and technology, computerization, and internet access. The convenience provided by BPJS in the form of innovation with the Mobile JKN application will facilitate the public in knowing this JKN service. As revealed in research about which states that:

"Innovation in the field of technology has mastered any sector and is everywhere. If in the past the Maslow's pyramid theory of needs states that the basic needs (physical needs) are the foundation of the pyramid, in the future what will be on the foundation of the pyramid is the data connection needs, aka the need for data access, because people seem to be unable to live without data access «(Arianti, Darma, Maradona, \& Mahyuni, 2019).

The things above are a picture of behavior towards the environment that has been synergized well so that it produces success in the implementation of UHC although it still needs socialization and improvement on certain sides. So it can be concluded that the implementation of UHC in Klungkung Regency is also based on the harmonization of human relations with the environment based on behavioral theory.

If viewed from the perspective of justice based on the dimensions of weakness it is clear that even the community recognizes that by maintaining cleanliness, germs will not be affected, this will bring good effects on health. Fair in this case means that not only do we 
demand that our environment have a positive impact on us, but we are expected to do justice by treating the environment well and then getting good.

In terms of management based on the dimensions of this weakness, it can be revealed that the environment here is in the form of existing and used facilities and infrastructure, in the form of buildings or houses that are occupied. So from $5 \mathrm{M} 1 \mathrm{H}$, the environment is the Material that is always needed in every management function. Of course the support from this environment on the success of UHC management in Klungkung Regency is enormous. The skills, effectiveness and efficiency of resources in this case the environment is an illustration of the harmony of the relationship with the environment when viewed from management theory. So that the conclusion of UHC Management in Klungkung Regency has been in accordance with the concept of weakness when viewed from management theory.

\section{CONCLUSION}

UHC in the Regency is a representation of the universal health insurance membership in Klungkung Regency which is already above $95 \%$. The things that underlie the success of UHC in Klungkung Regency are the high commitment of the highest policy makers in Klungkung Regency, namely the Regent of Klungkung by not setting aside all other stakeholders such as the Klungkung Regional Secretary, the head of the Health office, the head of the social service office, and the BPJS himself and other OPD who helped this success. Another basis is good management that has been applied in accordance with management principles. As well as community awareness itself which considers that health is a very important thing. The principle of justice, a relationship that must be balanced and harmonious is the most fundamental basis for this success. Tri Hita Karana which is a philosophy plays a very strong role in the success of government. So it can be concluded that it turns out that Tri Hita Karana has been applied in UHC Management in Klungkung Regency, both when examined from the theory of behavior, the theory of the principle of justice and management theory. Suggestion: that is in the concept of pawongan, it is expected that the organizers and implementers can ensure that information about JKN, type, membership, flow and so on can be disseminated more frequently and more targeted to all communities.

\section{REFERENCES}

1. Arianti, Ni Luh Novi, Darma, Gede Sri, Maradona, Agus Fredy, \& Mahyuni, Luh Putu. (2019). Menakar Keraguan Penggunaan QR Code Dalam Transaksi Bisnis. Jurnal IImiah Manajemen \& Bisnis, 16(2), 67-78.

2. Ayuni, Ni Made Sri, Gorda, Anak Agung Ngurah Eddy,. \& Budiasni, Ni Wayan Novi. (2019). Orientasi Kewirausahaan Saab Mote Desa Nagasepaha Sebagai Produk Ikonik. Jurnal IImiah Manajemen \& Bisnis, 4(1), 1-11.

3. BPS Bali. (2017). PAD Kabupaten di Bali Tahun 2017. https://bali.bps.go.id/news.html. Diakses tanggal 20 Juni 2018.

4. BPJS Kesehatan. (2019). https://bpjs-kesehatan.go.id/bpjs/post/categories/Mjl/berita. Diakses tanggal 20 Juni 2018.

5. BPJS Kesehatan. (2016). Peraturan Badan Penyelenggara Jaminan Sosial Kesehatan Nomor 1 Tahun 2016 Tentang Tata Cara Pendaftaran, Penagihan, Pembayaran dan Pelaporan luran Secara Online Bagi Peserta Pekerja Penerima Upah dari Badan Usaha Baru Dalam Rangka Kemudahan Berusaha. Jakarta: Direktur Utama Badan Penyelenggara Jaminan Sosial Kesehatan.

6. Depkes RI. (2009). Undang-Undang Republik Indonesia Nomor 36 Tahun 2009 Tentang Kesehatan. Jakarta: Kemenkes RI.

7. Dewantara, Agustinus. (2015). Pancasila Sebagai Pondasi Pendidikan Agama di Indonesia. Jurnal IImiah CIVIS, 5(1), 640-653.

8. Dinas Kesehatan Kabupaten Klungkung. (2018). Profil Kesehatan Kabupaten Klungkung 2018. Klungkung: Dinas Kesehatan Kabupaten Klungkung. 
9. Hardy, I.P.D.K, \& Yudha, N.L.G.A.N. (2018). Kemauan Dan Kemampuan Membayar (Ability - Willingness to Pay) Dalam Kepesertaan Jaminan Kesehatan Nasional Pada Sektor Informal Pedagang Pasar Tradisional Di Kota Denpasar 2017. Jurnal Kesehatan Terpadu, 2 (2), 96-100.

10. Irwan. (2017). Etika dan Perilaku Kesehatan (ed. ke-1). Yogyakarta, Bantul: CV. Absolute Media.

11. Kemenkes RI. (2018).Hasil Utama Riskesdas 2018. Jakarta: Badan Penelitian dan Pengembangan Kesehatan.

12. Mulyawan, I Putu Arya, Wirama, Dewa Gede, \& Badera, I Dewa Nyoman. (2017). Budaya Tri Hita Karana sebagai Pemoderasi Pengaruh Prinsip Good Corporate Governance pada Kinerja Lembaga Perkreditan Desa Di Kota Denpasar. E-Jurnal Ekonomi dan Bisnis Universitas Udayana, 6(8), 3193-3222.

13. Pinatih, I Gusti Bagus Ari, \& Gorda, Eddy Supriyadinata. (2017). Gaya Kepemimpinan, Beban Kerja, Stres Kerja, Teknologi Informasi, dan Kinerja Karyawan. Jurnal IImiah Manajemen \& Bisnis, 2(2), 298-310.

14. Prastiwi, Ni Luh Putu Eka, Ningsih, Luh Kartika, \& Suardika, I Ketut. (2019). Pola Pikir Dan Perilaku Kewirausahaan Umkm Di Buleleng. Jurnal Ilmiah Manajemen \& Bisnis, 4(1), 61-70.

15. Saputra, Komang Adi Kurniawan, Anggiriawan, Putu Adi, \& Sutapa, I Nyoman. (2018). Akuntabilitas Pengelolaan Keuangan Desa dalam Perspektif Budaya Tri Hita Karana. Jurnal Riset Akuntansi dan Bisnis Airlangga, 3(1), 306-321.

16. Suardikha, I Made Sadha, \& Budiasih, I Gusti Ayu Nyoman. (2017). Sistem Informasi Akutansi Berbasis Tri Hita Karana (THK). Denpasar: CV Sastra Utama.

17. Suryani, A.I, \& Suharyanto, A. (2016). Implementasi Program Badan Penyelenggara Jaminan Kesehatan (BPJS) Dalam Meningkatkan Pelayanan Administrasi Kesehatan di Rumah Sakit Umum Sibuhuan Kabupaten Padang Lawas. Jurnal IImu Administrasi Publik, 4(1), 86-99.

18. Yandrizall, Rifa'il, \& Utami, S.P. (2015). Analisis Kemampuan Dan Kemauan Membayar luran Terhadap Pencapaian UHC Jkn Di Kota Bengkulu. Jurnal Kesehatan Masyarakat Universitas Andalas, 10(1), 3-10. 